Article

\title{
Factors Affecting Pandemic Biosecurity Behaviors of International Travelers: Moderating Roles of Gender, Age, and Travel Frequency
}

\author{
Myung Ja Kim ${ }^{1, *}$, C. Michael Hall $2,3,4,5, * \mathbb{C}$ and Mark Bonn ${ }^{6, *}$ \\ 1 The College of Hotel \& Tourism Management, Kyung Hee University, Seoul 02447, Korea \\ 2 Department of Management, Marketing and Entrepreneurship, University of Canterbury, \\ Christchurch 8140, New Zealand \\ 3 Geography Research Unit, University of Oulu, 90014 Oulu, Finland \\ 4 Ekonomihögskolan, Linnéuniversitet Universitetskajen, Landgången 6, 39182 Kalmar, Sweden \\ 5 Department of Service Management and Service Studies, Lund University, Campus Helsingborg, \\ 25108 Helsingborg, Sweden \\ 6 Dedman School of Hospitality \& Tourism Management, Florida State University, \\ Tallahassee, FL 32306-2541, USA \\ * Correspondence: silver@khu.ac.kr (M.J.K.); michael.hall@canterbury.ac.nz (C.M.H.); \\ mbonn@dedman.fsu.edu (M.B.); Tel.: +82-10-9035-2696 (M.J.K.); +1-850-567-1826 (M.B.); \\ Fax: +82-2-961-0549 (M.J.K.); +1-850-644-5565 (M.B.)
}

Citation: Kim, M.J.; Hall, C.M.; Bonn, M. Factors Affecting Pandemic Biosecurity Behaviors of International Travelers: Moderating Roles of Gender, Age, and Travel Frequency. Sustainability 2021, 13, 12332. https://doi.org/10.3390/su132112332

Academic Editor: Frank Witlox

Received: 23 September 2021

Accepted: 3 November 2021

Published: 8 November 2021

Publisher's Note: MDPI stays neutral with regard to jurisdictional claims in published maps and institutional affiliations.

Copyright: (c) 2021 by the authors. Licensee MDPI, Basel, Switzerland. This article is an open access article distributed under the terms and conditions of the Creative Commons Attribution (CC BY) license (https:// creativecommons.org/licenses/by/ $4.0 /)$.

\begin{abstract}
Research undertaken during the COVID-19 pandemic has identified a number of significant factors that affect international travelers' biosecurity behavior. Tourists' age and gender as well as travel frequency have been found to have significant impacts on consumers' non-pharmaceutical intervention practices. However, despite the importance of age, gender, and travel frequency, such studies have overlooked international tourists' values, attitudes, interventions, and behaviors relevant to biosecurity during a pandemic. In order to bridge this gap, the purposes of this study are to build and test a conceptually comprehensive framework on the relationships between values, attitudes, interventions, and behaviors, along with the moderating effects of age, gender, and travel frequency. To meet the study objectives, a digital survey was administered during 1-5 September 2020, which generated $n=386$ total useable responses. Data were analyzed using the partial least squares approach. The results revealed that tourists' values have the greatest effect on their attitudes toward COVID-19 biosecurity for travel, which in turn positively influences interventions and behaviors. Interventions also have a significant impact on travelers' COVID-19 biosecurity behavior. This study expands the theoretical understanding of biosecurity and pandemic behavior. The findings of this research also provide significant insights to the literature as well as stakeholders, such as governments, health organizations, international health and tourism agencies, and destinations, with respect to managing international travel biosecurity measures.
\end{abstract}

Keywords: values; attitudes; interventions; biosecurity behaviors; gender; age; international travel frequency; COVID-19; United States

\section{Introduction}

Since the report of a novel coronavirus (COVID-19) in December 2019, in Wuhan, People's Republic of China, and the subsequent imposition of non-pharmaceutical interventions (NPIs) and biosecurity measures to reduce contagion, international tourism passenger flows have been unprecedently affected, resulting in significant damage to the tourism industry [1-3]. Behavioral interventions to ensure that travelers follow appropriate biosecurity and health measures to protect populations from transmissible infectious agents have long been recognized as vital measures in ensuring that international travel does not act as a vector for the introduction of infectious diseases or alien fauna and flora between 
countries [4-8]. Developing more effective global surveillance tools and mechanisms (e.g., biosecurity behaviors) to better communicate and coordinate between countries can facilitate more rapid and effective responses to infectious disease outbreaks [9]. However, ensuring that tourists follow biosecurity measures also requires the development of effective health marketing and communication strategies that are grounded in an understanding of tourist behavior [10]. Such information is also going to be extremely important as international travel recommences and new campaigns are developed to encourage international tourists to follow appropriate destination health protocols, which include NPIs as well as vaccination requirements [11,12].

Tourism-related biosecurity behaviors have been shown to be influenced by perceived values with respect to sustainability practices and attitudes toward sustainability [13]. Experiences of previous pandemics show that tourist NPIs can have a significant impact on the behavioral intentions of consumers to travel internationally [14]. In seeking to segment the international travel market to intervene more effectively in modifying health-related behaviors, age and gender have been found to be significant in travel-related incidence of infectious diseases (e.g., Chlamydia trachomatis) [15] as well as biosecurity behaviors [16].

In terms of different traveler characteristics, gender, age, and travel frequency have been found to be positively related to the risk of greater exposure to infectious diseases [17-19] and different levels of risk perception [20,21]. During COVID-19, demographic characteristics (e.g., age, gender) played key roles in influencing immunity levels and predicting mortality, while there are substantial gender-based differences for COVID-19-related psychosocial factors and adoption of preventive behaviors [22,23]. The frequency of travel and outdoor recreation participation also has significant effects on predicting traveling behavior $[24,25]$. Interestingly, international travel frequencies may also help predict biosecurity tourists' values, attitudes, and behaviors during the COVID-19 pandemic [26].

Despite the significance of biosecurity behaviors as a public and travel health measure, comprehensive studies of the factors affecting tourists' biosecurity behaviors are limited [5]. In order to fill this gap, the purposes of this study are to build and test a theoretically conceptualized research model on COVID-19 biosecurity for international travelers from the United States (US), including values, attitudes, interventions, and behaviors, together with three moderators representing gender, age, and travel frequency. To achieve these research goals, seven hypotheses are proposed, raising and verifying two research questions. First, do international tourists' values, attitudes, and interventions affect biosecurity behaviors during the COVID-19 pandemic? Second, do international travelers' gender, age, and travel frequency moderate the four relationships between values, attitudes, interventions, and biosecurity behaviors during the pandemic? In order to verify the research model, research questions, and hypotheses, we conducted a digital survey during the first year of COVID-19 with international travelers from the United States having substantial overseas travel experience. Accordingly, this study contributes to a better understanding of the variables that influence international travelers' biosecurity behaviors, providing theoretical and practical implications to stakeholders and/or future research.

\section{Literature Review}

\subsection{Theoretical Framework}

Biosecurity measures aim to prevent or slow the mobility of people and/or vectors in order to reduce the rate of contagion [5]. Tourism has thus become a focal point of biosecurity interventions undertaken by government and others during pandemics $[27,28]$. For example, long-distance commercial aircraft, ships, trains, buses, and automobiles may all be controlled and monitored in coordination with public health authorities in order to limit the spread of COVID-19 [29]. Although the implementation of biosecurity restrictions led to a reduction in international tourism globally because of the pandemic, considerations of biosecurity measures are also an element of tourism industry recovery and rebuilding plans because of the role they can play in restoring customer confidence and risk perceptions [30]. For example, the use of NPI biosecurity measures has been shown to be related to psycho- 
logical and financial resilience [31] as well as the experience of COVID-19, wearing masks, and entering quarantine [32]. Studies have also found that the value-attitude-behavior model and the moderating role of tourist's personalities are significant for COVID-19 biosecurity [33]. Researchers identified that tourist values, attitudes, personal norm, social norm, and tourist biosecurity behaviors are different depending on international travel frequency, while frequency has also been found to influence U.S. tourists' biosecurity behaviors [26]. However, despite the potential importance of values, attitudes, interventions, behaviors, tourist characteristics (e.g., gender and age), and travel frequency on international travel following a pandemic, comprehensive integrated research on how these factors influence international travel consumers' COVID-19 biosecurity behaviors is limited. Thus, this study aims to identify the relationships between the values, attitudes, interventions, and behaviors, along with the moderators of gender, age, and travel frequency in the context of COVID-19 biosecurity for international tourism.

\subsection{Hypothesis Development}

Attitudes towards COVID-19 health measures, including vaccination, can be derived from ascertaining people's values, which, in turn, are found to affect COVID-19-related decision-making behavior among United States adults [34]. In the context of sustainable tourism behaviors, consumers' perceived values have a great effect on their attitudes toward on sustainable consumption behavior [35]. United States travel consumers' values on biosecurity during the COVID-19 pandemic are also identified as highly influencing attitudes towards biosecurity [33]. Grounded in the literature review above, this study proposes the following hypothesis:

Hypothesis 1 (H1). Values on COVID-19 biosecurity for travel positively influence attitudes toward COVID-19 biosecurity for travel.

Public attitudes regarding various NPIs influence their adoption during COVID19 [36]. Strong attitudes have been found to be a good predictor of the adoption of four personal NPIs (handwashing, proper coughing habits, social distancing, and mask wearing) [37]. Attitudes regarding COVID-19 and the government/health system appear likely to influence compliance with preventive measures such as self-reporting, physical distancing, the use of face masks, and the acceptability of vaccines [38]. Drawing on this literature, this study posits the following hypothesis:

Hypothesis 2 (H2). Attitudes toward COVID-19 biosecurity for travel positively influence COVID-19 interventions for travel.

Individual attitudes toward COVID-19-related public health measures are closely related to compliance behavior with respect to such public health rules [39]. From a tourism sustainability perspective, consumers' attitudes have a significant impact on their behavior in relation to environmentally friendly consumption [35]. During the COVID-19 pandemic, international travel consumers' attitudes positively lead to their biosecurity behavior on COVID-19 [33]. Based on the literature review above, this study suggests the following hypothesis:

Hypothesis 3 (H3). Attitudes toward COVID-19 biosecurity for travel positively influence COVID-19 biosecurity behaviors for travel.

In the context of the 2009 H1N1 influenza pandemic, international travel consumers' NPIs were found to have a significant influence on their behavioral intention [14]. During the COVID-19 pandemic, travelers' NPIs significantly affected behavioral intention [40]. Furthermore, destination requirements for international travel consumers to adopt NPIs have a strong effect on their biosecurity behavior for travel during the COVID-19 pandemic [31]. In line with this literature, this study proposes the following hypothesis: 
Hypothesis 4 (H4). COVID-19 interventions for travel positively influence COVID-19 biosecurity behaviors for travel.

Gender and age groups often display different infectious disease profiles in high incidence destinations [15]. For instance, in a cross-national study across eight countries, women were found to be more likely to perceive COVID-19 as a very serious health problem, to agree with restraining public policy measures, and to comply with them [39]. In terms of the COVID-19 pandemic, significant gender-based differences for both psychosocial factors and the adoption of preventive behaviors have been found [22]. Different age-related influences on individuals' reactions to the pandemic and vacation preferences also provide practical insights for stakeholders interested in revising their segmentation and targeting strategies once the pandemic subsides [41]. In light of this literature, this study assumes the two following hypotheses:

Hypothesis 5 (H5). Gender significantly moderates the relationships between values, attitudes, interventions, and behaviors in the context of COVID-19 biosecurity for tourism.

Hypothesis 6 (H6). Age significantly moderates the relationships between values, attitudes, interventions, and behaviors in the context of COVID-19 biosecurity for tourism.

In terms of travel frequency, significant effects have been found of the frequency of travel on mobility-resource ownership decisions [25]. Travel frequency has a strong influence on the spread of infectious diseases (e.g., COVID-19), and there are close relationships between frequency and basic reproduction numbers and global dynamics [19]. As well as contributing to the spread of novel diseases, travel frequency also has a great impact on the persistence of infectious diseases, such as mosquito-borne diseases [18]. Interestingly, travel frequency may also be related to other travel behavior. For example, travel frequency can predict consumer behavior of leisurely walking, travel time, and/or activities in the context of outdoor recreation participation [24]. Importantly, there is a suggestion that biosecurity behaviors may be related to international travel frequency [26]. Therefore, this study proposes the following hypothesis:

Hypothesis 7 (H7). Travel frequency significantly moderates the relationships between values, attitudes, interventions, and behaviors in the context of COVID-19 biosecurity for tourism.

Figure 1 displays the hypothesized relationships among values, attitudes, interventions, and behaviors, along with the three moderators of gender, age, and travel frequency. 


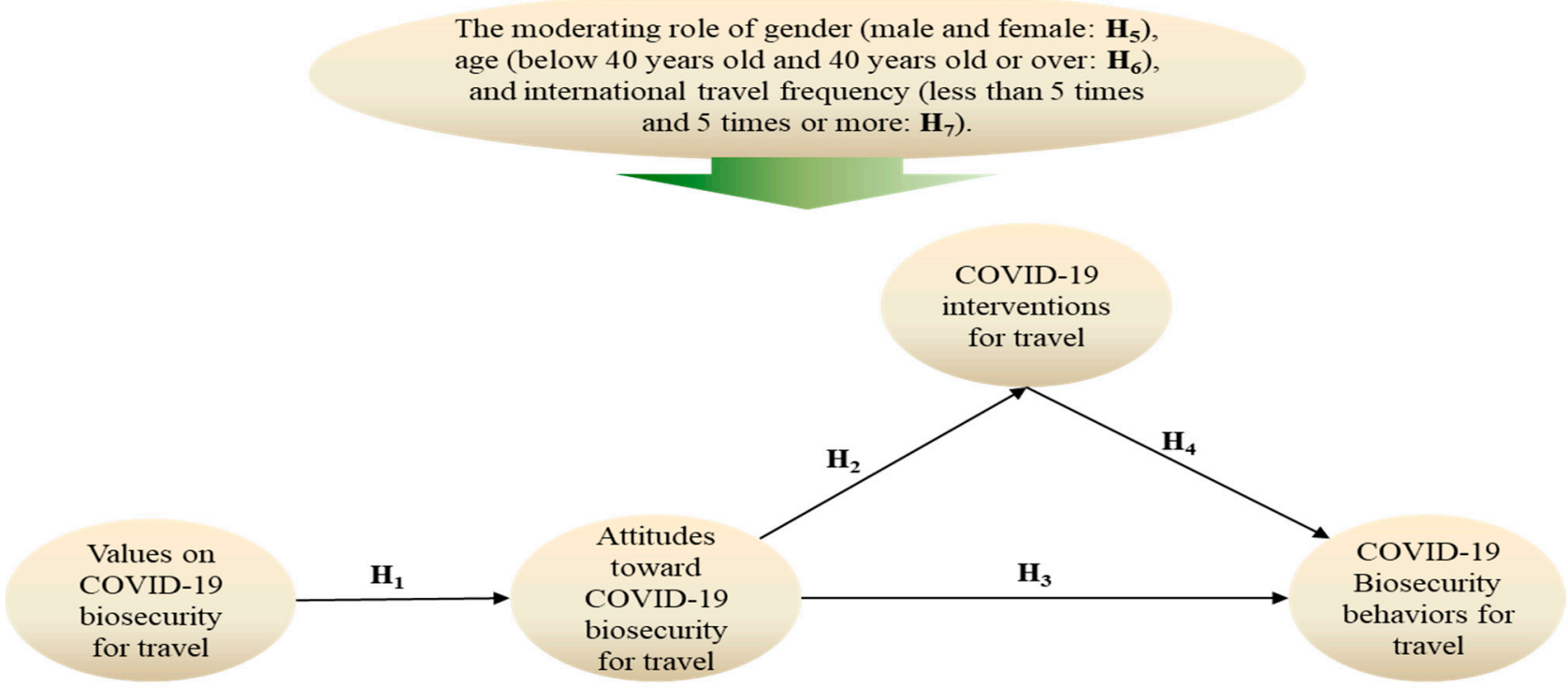

Figure 1. Proposed research model.

\section{Methods}

\subsection{Measurement}

This study has applied prior validated multi-measurement questions, which were reworded to fit the study context [42]. The measurements consist of 18 items that measure four constructs, including the following: values on COVID-19, attitudes toward COVID-19 biosecurity, COVID-19 interventions of travel, and COVID-19 biosecurity behaviors for travel. Six items addressing values on COVID-19 biosecurity for travel were generated from previous studies (e.g., "Participating in human biosecurity is an ethically right action when traveling during the pandemic") [26]. Three items relevant to attitudes toward biosecurity for travel were based on existing literature (e.g., "Participating in human biosecurity is an ethically right action when traveling during the pandemic") [7]. Three items regarding COVID-19 interventions for travel were adapted from past research (e.g., "Participating in human biosecurity is an ethically right action when traveling during the pandemic") [13]. COVID-19 biosecurity behaviors for travel were assessed using six questions formed from Hall (e.g., "When traveling during the pandemic, I keep away from those who have the symptoms of COVID-19") [4,5].

\subsection{Content Validity and Pre-Test}

In order to evaluate content validity, three scholars who are experts in health and travel relationships assessed the question items. In light of advice gained on the application of NPIs during pandemics [43], four questions related to COVID-19 biosecurity behaviors for travel were added to better capture the concept accordingly (e.g., "I refrain from touching my eyes, nose, and mouth when traveling during the pandemic"). A pre-test was subsequently conducted on 40 U.S. residents who had previously traveled overseas within the past five years. Two questions about guaranteeing the quality of survey data and time spent for answering all items were added based upon the pre-test (Appendix A).

\subsection{Data Collection}

Large panel digital surveys are frequently applied in research because of their capacity to obtain responses rapidly and in a cost-effective manner [31,44]. For collecting valid data, this study utilized the online survey firm Qualtrics, which possesses one of the world's largest panels, as well as following and adhering to rigorous online survey procedures [45]. Based on data from the U.S. National Travel and Tourism Office [46], respondents were drawn from a Qualtrics panel using a quota sampling technique according to age (18 and 
over) and gender of outbound tourists. In order to ensure commitment to the provision of considered and honest answers as well as overseas trip experience, respondents were selected via two screening questions. Scaled questions were rotated to avoid response bias. The online survey was administered on 1-5 September 2020. Inappropriate responses were excluded from the dataset by analyzing $\mathrm{p}-\mathrm{p}$ plots and correlations regarding time spent on answering all the questions, as respondents who took less than the appropriate time were found to insignificantly correlate with responses from respondents that completed the survey with the established timeframe. After deleting respondents who finished the questionnaire in less than three minutes, 411 qualified responses were obtained for the analysis. In addition, 25 respondents who indicated they had no plans for international travel when COVID-19 ends were eliminated from the data set. Thus, a total of 386 useable responses were analyzed.

\subsection{Data Analysis}

This study utilized partial least squares (PLS)-structural equation modelling (SEM) with multi-group analysis [47]. With formative second-order constructs, PLS-SEM is useful in estimating first-order constructs concurrently [48]. PLS-SEM is also better than typical SEM (e.g., covariance based) for non-normal data, small samples, and/or complicated models with MGA [49]. The data in this research have a non-normal distribution with over 1.000 as absolute values of the items for skewness and/or kurtosis, as shown in Table 1. For these reasons, this study utilized SmartPLS 3.2.2 to validate the measurement and structural models [47]. To verify the moderating effect of low and high big five personality groups, the researchers also used MGA according to PLS-SEM algorithms [50,51].

Table 1. Confirmatory factor analysis (CFA) and descriptive statistics.

\begin{tabular}{|c|c|c|c|c|c|c|c|}
\hline Constructs & Items & $\begin{array}{l}\text { Factor } \\
\text { Loading }\end{array}$ & Mean & $\begin{array}{l}\text { Standard } \\
\text { Deviation }\end{array}$ & Kurtosis & Skewness & VIF $^{* *}$ \\
\hline \multirow{6}{*}{$\begin{array}{l}\text { Values on COVID-19 } \\
\text { biosecurity for travel }\end{array}$} & Item 1 & 0.804 & 5.513 & 1.642 & 0.587 & -1.127 & 2.262 \\
\hline & Item 2 & 0.813 & 5.440 & 1.634 & 0.782 & -1.170 & 2.767 \\
\hline & Item 3 & 0.796 & 5.438 & 1.599 & 0.538 & -1.058 & 2.454 \\
\hline & Item 4 & 0.856 & 5.598 & 1.587 & 1.274 & -1.347 & 3.390 \\
\hline & Item 5 & 0.865 & 5.588 & 1.553 & 1.188 & -1.270 & 3.138 \\
\hline & Item 6 & 0.844 & 5.539 & 1.597 & 1.078 & -1.275 & 3.008 \\
\hline \multirow{3}{*}{$\begin{array}{l}\text { Attitudes toward COVID-19 } \\
\text { biosecurity for travel }\end{array}$} & Item 1 & 0.924 & 5.666 & 1.486 & 1.121 & -1.251 & 3.380 \\
\hline & Item 2 & 0.931 & 5.661 & 1.474 & 1.170 & -1.253 & 3.043 \\
\hline & Item 3 & 0.918 & 5.671 & 1.439 & 1.527 & -1.322 & 3.380 \\
\hline \multirow{3}{*}{$\begin{array}{l}\text { COVID-19 interventions for } \\
\text { travel }\end{array}$} & Item 1 & 0.877 & 5.927 & 1.339 & 2.303 & -1.544 & 1.982 \\
\hline & Item 2 & 0.868 & 5.863 & 1.407 & 1.746 & -1.454 & 2.043 \\
\hline & Item 3 & 0.872 & 6.000 & 1.327 & 2.565 & -1.642 & 1.982 \\
\hline \multirow{10}{*}{$\begin{array}{l}\text { COVID-19 Biosecurity } \\
\text { behaviors for travel }\end{array}$} & Item 1 & 0.834 & 6.016 & 1.410 & 2.261 & -1.646 & 2.562 \\
\hline & Item 2 & 0.812 & 5.775 & 1.423 & 1.299 & -1.315 & 2.463 \\
\hline & Item $3 *$ & - & - & - & - & - & - \\
\hline & Item $4 *$ & - & - & - & - & - & - \\
\hline & Item 5 & 0.831 & 5.979 & 1.313 & 2.948 & -1.691 & 2.676 \\
\hline & Item 6 & 0.825 & 6.031 & 1.303 & 2.755 & -1.693 & 2.534 \\
\hline & Item 7 & 0.756 & 5.712 & 1.481 & 1.423 & -1.345 & 2.038 \\
\hline & Item 8 & 0.778 & 5.956 & 1.302 & 2.059 & -1.474 & 2.112 \\
\hline & Item 9 & 0.830 & 6.104 & 1.283 & 3.236 & -1.796 & 2.475 \\
\hline & Item 10 & 0.771 & 5.813 & 1.378 & 1.546 & -1.356 & 2.349 \\
\hline
\end{tabular}

Note: * Items are deleted after CFA. ** Variance inflation factor of multicollinearity. Items in italics have a non-normal distribution. 


\section{Results}

Three moderators were assessed by demographic and general questions (i.e., gender, age, and international travel frequency in the past five years) (Appendix A). In order to test the moderating effects, gender (male and female: H5), age (below 40 years old and 40 years old or over: H6), and international travel frequency in the past five years (less than five times and five times or more: H7) were divided into two groups. Sample profiles of demographics and general questions are provided in Table 2.

Table 2. Demographic characteristic and general information of the entire group.

\begin{tabular}{|c|c|c|c|c|c|}
\hline Characteristics & $\begin{array}{c}n \\
(386)\end{array}$ & $\begin{array}{c}\% \\
(100)\end{array}$ & Characteristics & $\begin{array}{c}n \\
(386)\end{array}$ & $\begin{array}{c}\% \\
(100)\end{array}$ \\
\hline Gender & & & Monthly household income & & \\
\hline Male & 187 & 48.4 & Less than US \$2000 to 3999 & 121 & 31.2 \\
\hline Female & 196 & 50.8 & US $\$ 4000$ to 7999 & 135 & 35.0 \\
\hline Other & 3 & 0.8 & US $\$ 8000$ or more & 130 & 33.8 \\
\hline Age & & & $\begin{array}{l}\text { Overseas travel frequency in the pas } \\
5 \text { years }\end{array}$ & & \\
\hline Between 18 and 39 years old & 203 & 52.6 & Less than 5 times & 193 & 50.0 \\
\hline 40 years old and over & 183 & 47.4 & 5 times and over & 193 & 50.0 \\
\hline Educational level & & & Had COVID-19 & & \\
\hline Less than or high school diploma & 41 & 10.6 & Yes & 40 & 10.4 \\
\hline 2-year college & 77 & 20.0 & No & 346 & 89.6 \\
\hline University & 134 & 34.7 & $\begin{array}{l}\text { Know someone who have/had } \\
\text { COVID-19 }\end{array}$ & & \\
\hline Graduate school or higher & 134 & 34.7 & Yes & 212 & 54.9 \\
\hline Marital status & & & No & 174 & 45.1 \\
\hline Single & 129 & 33.4 & Cancel a trip than wear masks & & \\
\hline Married & 240 & 62.2 & Yes & 140 & 36.3 \\
\hline Divorce, widow/er, living together & 17 & 4.4 & No & 246 & 63.0 \\
\hline Occupation & & & Cancel a trip than enter quarantine & & \\
\hline Professional (e.g., attorney, engineer) & 117 & 30.4 & Yes & 242 & 62.7 \\
\hline Business owner/self-employed & 45 & 11.7 & No & 144 & 37.3 \\
\hline Service worker & 44 & 11.4 & Residential area & & \\
\hline Office/administrative/clerical worker & 46 & 11.9 & Northeast & 132 & 34.1 \\
\hline Civil servant (government) & 10 & 2.6 & South & 135 & 34.8 \\
\hline Home maker & 11 & 2.8 & Midwest & 55 & 14.3 \\
\hline Student & 25 & 6.5 & West & 60 & 15.8 \\
\hline Retiree & 46 & 11.9 & Alaska & 2 & 0.5 \\
\hline Unemployed & 16 & 4.1 & Hawaii & 2 & 0.5 \\
\hline Other (e.g., flight attendant, CEO) & 26 & 6.7 & & & \\
\hline
\end{tabular}

The results of the measurement and structural model assessments fitted all the required criteria well [30] (Tables 1 and 3). As the data had non-normal distributions by both skewness as well as kurtosis, this study utilized PLS-SEM to assess the seven hypotheses, applying bootstraps of 5000 re-sampling techniques. H1, H2, H3, and H4 were highly supported (Figure 2). Specifically, values have the greatest effect on attitudes with respect to COVID-19 biosecurity during traveling in this study's research model. Interestingly, attitudes have more impact on interventions than behaviors relevant to biosecurity. Behaviors are also influenced more by interventions than attitudes, showing the important mediating role of interventions. 
Table 3. Reliability and discriminant validity.

\begin{tabular}{cccc}
\hline Construct & \multicolumn{3}{c}{ Correlation of the Constructs } \\
\cline { 2 - 4 } & $\mathbf{1}$ & $\mathbf{2}$ & $\mathbf{3}$ \\
\hline 1. Values on COVID-19 biosecurity for travel & & & \\
2. Attitudes toward COVID-19 biosecurity for travel & 0.889 & 0.770 & 0.828 \\
3. COVID-19 interventions for travel & 0.709 & 0.761 & 0.842 \\
4. COVID-19 biosecurity behaviors for travel & 0.751 & 0.915 & 0.844 \\
Cronbach's alpha $\geq 0.7$ & 0.910 & 0.915 & 0.905 \\
Rho_A (reliability coefficient) $\geq 0.7$ & 0.912 & 0.946 & 0.926 \\
Composite reliability $\geq 0.7$ & 0.689 & 0.854 & 0.936 \\
AVE $\geq 0.5 \quad$ & & 0.557 & 0.648 \\
Effect size $\left(Q^{2}\right)>0$ & Standardised root mean residual (SRMR): $0.064<0.08$ & 0.390 \\
\hline
\end{tabular}

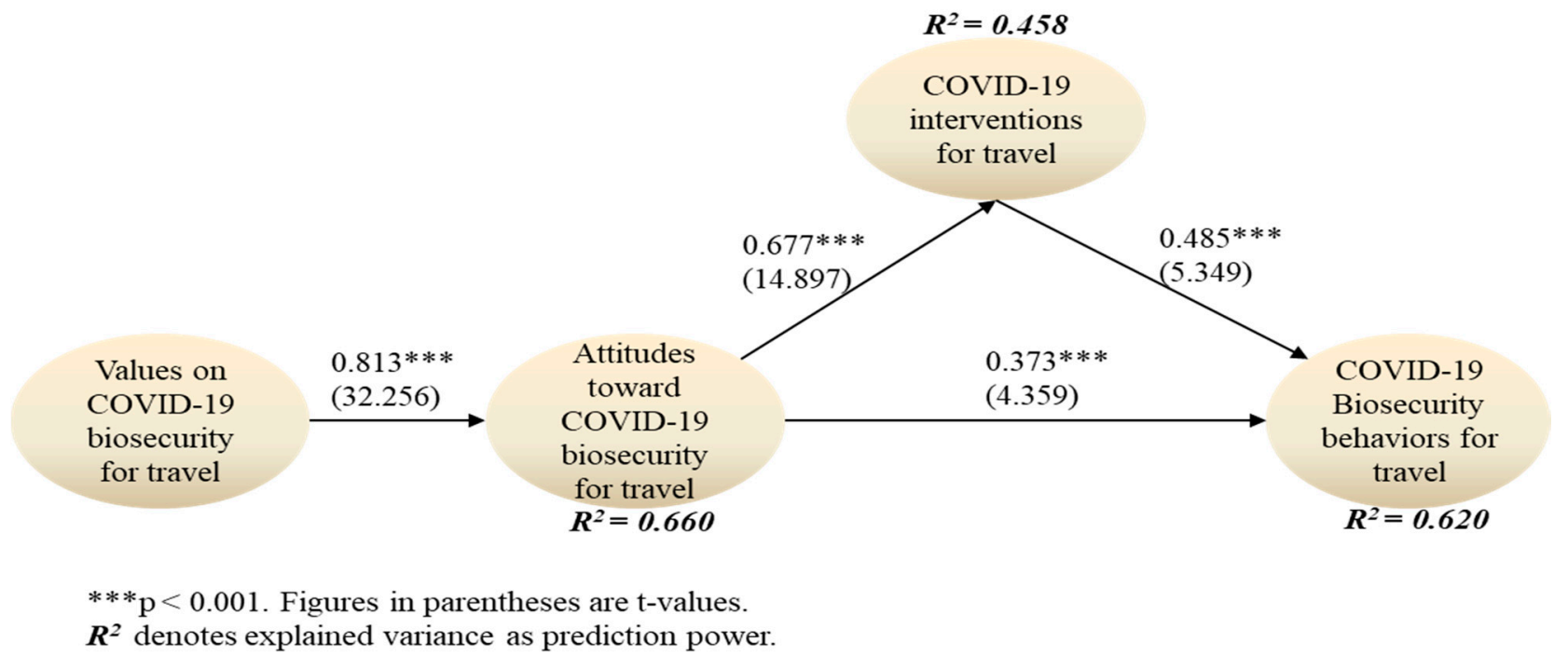

Figure 2. Results of path analysis.

With regard to the moderating effects, H6 and H7 were fully supported, but H5 was partially supported (Table 4). For example, the relationship between attitudes and behaviors has greater effects in males than in females, while the relationship between interventions and behaviors has a stronger impact upon females. In addition, the relationships between values and attitudes, attitudes and interventions, and interventions and behaviors have larger influences upon those 40 years or older, while the relationship between attitudes and behaviors has a larger influence for those less than 40 years old. More frequent international travelers have greater effects on the four relationships between values, attitudes, interventions, and behaviors than their counterparts. 
Table 4. Comparison of the path coefficients between four moderators.

\begin{tabular}{|c|c|c|c|c|c|c|c|}
\hline Moderator & $\mathbf{H}$ & Path & Group A & Group B & $\begin{array}{c}t \text {-Value } \\
\text { (A-B) }\end{array}$ & $\begin{array}{c}p \text {-Value } \\
\text { (A-B) }\end{array}$ & $\begin{array}{c}\text { Hypothesis } \\
\text { Test }\end{array}$ \\
\hline \multirow[t]{4}{*}{$\begin{array}{c}\text { Gender: } \\
\text { Men (A); } \\
\text { Women (B) }\end{array}$} & H5a & $\begin{array}{c}\text { Values on COVID-19 } \\
\text { biosecurity } \\
\text { for travel } \rightarrow \text { Attitudes toward } \\
\text { COVID-19 } \\
\text { biosecurity for travel }\end{array}$ & $0.813^{* * *}$ & $0.816^{* * *}$ & -0.890 & $>0.05$ & \multirow[t]{4}{*}{$\begin{array}{c}\text { Partially } \\
\text { supported }\end{array}$} \\
\hline & $\mathrm{H} 5 \mathrm{~b}$ & $\begin{array}{l}\text { Attitudes toward COVID-19 } \\
\text { biosecurity for travel } \rightarrow \\
\text { COVID-19 interventions for } \\
\text { travel }\end{array}$ & $0.679 * * *$ & $0.678^{* * *}$ & 0.245 & $>0.05$ & \\
\hline & $\mathrm{H} 5 \mathrm{c}$ & $\begin{array}{l}\text { Attitudes toward COVID-19 } \\
\text { biosecurity for travel } \rightarrow \\
\text { COVID-19 Biosecurity } \\
\text { behaviors for travel }\end{array}$ & $0.496^{* * *}$ & $0.269^{* * *}$ & 19.865 & $<0.001$ & \\
\hline & H5d & $\begin{array}{l}\text { COVID-19 interventions for } \\
\text { travel } \rightarrow \text { COVID-19 } \\
\text { biosecurity behaviors for } \\
\text { travel }\end{array}$ & $0.307^{*}$ & $0.639^{* * *}$ & -27.748 & $<0.001$ & \\
\hline \multirow{4}{*}{$\begin{array}{c}\text { Age: } \\
\text { Below } 40 \\
\text { years old } \\
\text { (A); } \\
40 \text { years } \\
\text { old and } \\
\text { over (B) }\end{array}$} & H6a & $\begin{array}{c}\text { Values on COVID-19 } \\
\text { biosecurity } \\
\text { for travel } \rightarrow \text { Attitudes toward } \\
\text { COVID-19 } \\
\text { biosecurity for travel }\end{array}$ & $0.809^{* * *}$ & $0.818^{* * *}$ & -2.480 & $<0.05$ & \multirow[t]{4}{*}{$\begin{array}{c}\text { Fully } \\
\text { supported }\end{array}$} \\
\hline & $\mathrm{H} 6 \mathrm{~b}$ & $\begin{array}{l}\text { Attitudes toward COVID-19 } \\
\text { biosecurity for travel } \rightarrow \\
\text { COVID-19 interventions for } \\
\text { travel }\end{array}$ & $0.615^{* * *}$ & $0.752^{* * *}$ & -21.081 & $<0.001$ & \\
\hline & $\mathrm{H} 6 \mathrm{c}$ & $\begin{array}{c}\text { Attitudes toward COVID-19 } \\
\text { biosecurity for travel } \rightarrow \\
\text { COVID-19 biosecurity } \\
\text { behaviors for travel }\end{array}$ & $0.388^{* *}$ & $0.328^{* *}$ & 5.364 & $<0.001$ & \\
\hline & H6d & $\begin{array}{c}\text { COVID-19 interventions for } \\
\text { travel } \rightarrow \text { COVID-19 } \\
\text { biosecurity behaviors for } \\
\text { travel }\end{array}$ & $0.477^{* * *}$ & $0.519^{* * *}$ & -3.389 & $<0.001$ & \\
\hline \multirow{4}{*}{$\begin{array}{l}\text { Overseas } \\
\text { travel } \\
\text { frequency: } \\
5 \text { times and } \\
\text { more (A); } \\
\text { Less than } 5 \\
\text { times in the } \\
\text { past } 5 \text { years } \\
\text { (B) }\end{array}$} & $\mathrm{H} 7 \mathrm{a}$ & $\begin{array}{c}\text { Values on COVID-19 } \\
\text { biosecurity } \\
\text { for travel } \rightarrow \text { Attitudes toward } \\
\text { COVID-19 } \\
\text { biosecurity for travel }\end{array}$ & $0.837^{* * *}$ & $0.792 * * *$ & 13.118 & $<0.001$ & \multirow[t]{4}{*}{$\begin{array}{c}\text { Fully } \\
\text { supported }\end{array}$} \\
\hline & $\mathrm{H} 7 \mathrm{~b}$ & $\begin{array}{l}\text { Attitudes toward COVID-19 } \\
\text { biosecurity for travel } \rightarrow \\
\text { COVID-19 interventions for } \\
\text { travel }\end{array}$ & $0.697^{* * *}$ & $0.662^{* * *}$ & 5.183 & $<0.001$ & \\
\hline & $\mathrm{H} 7 \mathrm{c}$ & $\begin{array}{c}\text { Attitudes toward COVID-19 } \\
\text { biosecurity for travel } \rightarrow \\
\text { COVID-19 Biosecurity } \\
\text { behaviors for travel }\end{array}$ & $0.385^{* * *}$ & 0.341 * & 4.197 & $<0.001$ & \\
\hline & $\mathrm{H} 7 \mathrm{~d}$ & $\begin{array}{c}\text { COVID-19 interventions for } \\
\text { travel } \rightarrow \text { COVID-19 } \\
\text { biosecurity behaviors for } \\
\text { travel }\end{array}$ & $0.521^{* * *}$ & $0.485^{* * *}$ & 3.234 & $<0.01$ & \\
\hline
\end{tabular}




\section{Discussion and Conclusions}

\subsection{Discussion}

The results revealed that values with respect to the importance of biosecurity have the strongest impact on attitudes in terms of COVID-19-related biosecurity, implying that international tourists with high biosecurity values are more likely to have positive attitudes toward pandemic biosecurity behavior. This reinforces the basic, yet significant understanding that the pre-existing beliefs of overseas travelers towards prevention practices are very important with respect to perceptions of health safety measures, extending the findings of prior studies on the impact of values on attitudes [33,34]. Unexpectedly, interventions have a substantial mediating effect between attitudes and behaviors, showing that the nature of the NPIs is critical for tourist behavior. Attitudes toward pandemic biosecurity for travel greatly influence pandemic interventions for travel, revealing that people who travel internationally have positive attitudes on biosecurity and tend to accept pandemic-related interventions for travel, expanding previous findings on attitudes and NPIs [36-38]. In addition, attitudes substantially lead to pandemic biosecurity behaviors for tourism, broadening past research on attitudes and behaviors during a pandemic [33,39]. Importantly, pandemic interventions for tourism positively influence the biosecurity actions for tourism, broadening the existing literature on the topic $[14,19,40]$.

Regarding the gender moderator, the relationships between attitudes and behaviors, as well as interventions and behaviors, show the differences between males and females. The results infer that men with positive attitudes towards COVID-19 biosecurity for travel are more likely to practice appropriate biosecurity behaviors, while women with strong interventions of the COVID-19 pandemic for travel are more likely to follow biosecurity measures, which is partially consistent with the existing literature [15,22,39]. With regard to the two age groups, representing travelers below 40 years old and those 40 years old or over, it was found that older travel consumers tend to follow biosecurity rules more than younger travelers, although attitudes and behaviors remain important influences for younger travelers. These results are somewhat similar to previous research [22,41]. Significantly, for the determination of targeted interventions in terms of travel frequency, more frequent international travelers are more likely to follow recommended biosecurity behaviors than infrequent travelers. These findings show some similarity to prior travel frequency studies $[18,19,24-26]$.

\subsection{Theoretical Implications}

This study provides several theoretical contributions in terms of international travel behaviors and infectious disease control in responding to COVID-19, which are particularly relevant given the pandemic's potential longer-term effects with respect to travel practices and consumer attitudes toward tourism [52]. First, this study found that values, attitudes, and interventions are key factors that lead to travel consumers' adoption of recommended biosecurity behaviors. The finding of this study provides new knowledge to researchers and public health educators. Second, this research sheds specific light on international travel-related pandemic interventions, revealing the important mediating role of NPIs between attitudes and behaviors. These results, therefore, offer significant insights into the linkage of attitudes, interventions, and behaviors for future studies on tourism and COVID-19 as well as tourism and infectious disease in general [5].

With respect to the moderating role of gender, men are more likely to have positive relationships between values and attitudes, and attitudes and interventions. In contrast, women are more likely to have positive relationships between attitudes and behaviors, and interventions and behavior. With respect to the moderating effect of age, older tourists tend to have stronger relationships between values and attitudes, attitudes and interventions, and interventions and behaviors, whereas younger tourists tend to have stronger relationship between attitudes and behaviors. These findings provide novel insights. Interestingly, with respect to the moderating role of tourism frequency, the research model supported that international tourists who travel more frequently have stronger relationships. 


\subsection{Practical Implications}

The findings of this work offer several practical implications for those responsible for international travelers following biosecurity measures. First, the high impact of values on attitudes in this study suggests that governments and tourism destinations should focus on promoting biosecurity values to potential overseas tourists in order to improve their attitudes toward pandemic biosecurity behaviors at destinations and when using transport. The mediating role of interventions between attitudes and behaviors also suggests that international and national health agencies and destination management organizations should emphasize the significance of NPIs to increase the willingness to adopt appropriate biosecurity behaviors when traveling while COVID-19 remains active. This could partly be done by online and mobile education campaigns as well as through social media networks and relevant print services to communicate to international tourists before and during travel to a destination [53]. The greater impact of interventions on behaviors than that of attitudes on behaviors suggests that policy makers and marketers should create strategies utilizing NPIs when they want overseas travelers to take biosecurity actions relevant to disease control.

The significant moderating effects of gender, age, and travel frequency provide clear insights for the better targeting and design of marketing and communication strategies when they wish to target international travel consumers to improve biosecurity behavior. For example, when targeting men, governments and health organizations can focus on the relationships between attitudes and behaviors as well as interventions and behaviors. This can be done by market segmentation strategies via different digital campaign contents for men or women separately. The different findings with respect to older and younger tourists suggest that marketing messages can be developed and targeted by age. That is, when targeting older people, stakeholders could emphasize the values and interventions, while when targeting younger people, attitudes and behaviors would be highlighted. That could be implemented by advertising through different types of social media channels depending on age categories. The relationship between frequency of travel and biosecurity behaviors also provides clear opportunities for effective communication via frequent flier programs as well as the potential role for social norm-based travel behavioral interventions. Owing to the strength of relationships from all hypotheses in the high frequency travel group compared with the low frequency travel group, frequency of travel clearly becomes a valuable tool for the development of marketing plans regarding tourism-related pandemic biosecurity actions.

\subsection{Limitations and Future Research Directions}

Although this work contributes to both theory and practice, there are several limits to the study to consider for future research opportunities. As this study was conducted on U.S. international tourists during the COVID-19 pandemic, the results need to be treated cautiously with respect to other countries, cultures, and time periods. Because demographic factors have significant impacts on COVID-19 biosecurity practices, future research on income, education, marital status, and/or place of residence are recommended. These findings might also provide interesting insights for improved segmentation measures in the development of behavioral interventions to restrict infectious disease risk and the receptiveness of biosecurity measures to voluntary adoption during international travel.

Older travel consumers (60 years and older) can have substantially different behaviors from those of other age categories regarding pandemic biosecurity for tourism. Consequently, future studies may need focus on multiple age segments of travelers to identify similarities and differences among those segments. Furthermore, future research should attempt to compare United States-based international travelers with those international travel consumers residing in different geographical regions to compare differences and similarities. Finally, the development of COVID-19 vaccine passports for the resumption of tourism is underway [54], although NPIs will potentially still be required at some destinations and especially during periods of future outbreaks. Accordingly, new research addressing 
the implications of vaccination for international tourism, both as a single variable and in conjunction with NPIs, would be valuable and timely.

Author Contributions: M.J.K. organized the research, conducted the empirical study, analyzed the data, and wrote the manuscript. C.M.H. provided the seminal ideas, developed the questionnaire, and wrote and edited the manuscript. M.B. developed the sampling frame, managed the data collection process with Qualtrics, and edited the manuscript. All authors have read and agreed to the published version of the manuscript.

Funding: This research received no external funding.

Institutional Review Board Statement: Not applicable.

Informed Consent Statement: Informed consent was obtained from all subjects involved in the study.

Data Availability Statement: The data presented in this study are available on request from the first author. The data are not publicly available for ethical reasons.

Acknowledgments: This work was supported by the Florida State University. The authors would like to thank the anonymous reviewers and the editor for their constructive comments and suggestions for this paper.

Conflicts of Interest: The authors declared no potential conflicts of interest with respect to the research, authorship, and/or publication of this article.

Appendix A. Questionnaire on Biosecurity and Tourism

XXX university and a team of international researchers are conducting a study regarding biosecurity and tourism during the COVID-19 pandemic. Your sincere response will contribute to a better understanding of consumer behavior related to biosecurity, the introduction of exotic fauna and flora, disease control, and sustainability. Your response is completely anonymous and will be used only for academic purposes.

We would greatly appreciate your time and cooperation in completing this questionnaire.

Thank you very much!

Researchers:

Names of the researchers and university are eliminated for anonymity. The layout of this questionnaire is only for MS word file which is quite different from the online survey screen.

1-5 September 2020.

We care about the quality of our survey data and hope to receive the most accurate measures of your opinions, so it is important to us that you thoughtfully provide your best answer to each question in the survey.

Do you commit to providing your thoughtful and honest answers to the questions in this survey?

1. I will provide my best answers: Go to the next question.

2. I will not provide my best answers: End the survey.

3. I can't promise either way: End the survey.

Screen question (SQ)

SQ1. Have you ever traveled internationally?

(1) Yes If you checked "yes," please answer the following GQ1 question. 
(2) No: Close the survey (We thank you for your time spent taking this survey. Your respose has been recorded.).

General question (GQ)

GQ1. Do you plan to travel internationally if the pandemic ends?

(1) Yes (2) No

GQ2. How many times have you traveled internationally in the past 5 years? times.

GQ3. Did/do you have COVID-19?

(1) Yes (2) No

GQ4. Do you know someone who have/had COVID-19?

(1) Yes (2) No

GQ5. Would you rather cancel a trip than wear masks?

(1) Yes (2) No

GQ6. Would you rather cancel a trip than enter quarantine?

(1) Yes (2) No

Note 1: Biosecurity is the protection of the economic, environmental, and/or human health in a country, region, or location from the introduction, emergence, establishment, and spread of harmful organisms (pests and diseases). In this study, biosecurity refers to measures that are taken to stop the spread or introduction of organisms potentially harmful to human, animal, and plant life. The main aim of biosecurity is to protect human health, agriculture, forestry, fishing, and the environment through the prevention, control, and management of biological risk factors, such as the introduction of plant or animal pests, or a disease (e.g., COVID-19).

Note 2: In this study, travel, traveling, tourism, and tourists mean international travel, traveling, tourism, and tourists.

\section{Construct question (CQ)}

CQ1. Please carefully read each item and check the score that you think best fits [select one for each] (1: strongly disagree; 2: disagree; 3 : somewhat disagree; 4: neither agree nor disagree; 5: somewhat agree; 6: agree; 7: strongly agree).

\begin{tabular}{|c|c|c|c|c|c|c|c|}
\hline $\begin{array}{l}\text { CQ1. Values on COVID-19 } \\
\text { Biosecurity for Travel }\end{array}$ & $\begin{array}{l}\text { Strongly } \\
\text { Disagree }\end{array}$ & Disagree & $\begin{array}{l}\text { Somewhat } \\
\text { Disagree }\end{array}$ & $\begin{array}{l}\text { Neither } \\
\text { Agree nor } \\
\text { Disagree }\end{array}$ & $\begin{array}{c}\text { Somewhat } \\
\text { Agree }\end{array}$ & Agree & $\begin{array}{c}\text { Strongly } \\
\text { Agree }\end{array}$ \\
\hline 1-8 1. Participating in human & & & & & & & \\
\hline $\begin{array}{l}\text { biosecurity is an ethically right action } \\
\text { when traveling during the pandemic. }\end{array}$ & 1 & 2 & 3 & 4 & 5 & 6 & 7 \\
\hline $\begin{array}{l}\text { 2. Practicing animal biosecurity is a } \\
\text { moral duty when traveling } \\
\text { during the pandemic. }\end{array}$ & 1 & 2 & 3 & 4 & 5 & 6 & 7 \\
\hline $\begin{array}{l}\text { 3. Supporting plant biosecurity is a } \\
\text { virtuous behavior when traveling } \\
\text { during the pandemic. }\end{array}$ & 1 & 2 & 3 & 4 & 5 & 6 & 7 \\
\hline $\begin{array}{l}\text { 4. Wearing a mask helps biosecurity } \\
\text { when traveling during the } \\
\text { pandemic. }\end{array}$ & 1 & 2 & 3 & 4 & 5 & 6 & 7 \\
\hline $\begin{array}{l}\text { 5. Social or physical distancing } \\
\text { contributes to biosecurity when } \\
\text { traveling during the pandemic. }\end{array}$ & 1 & 2 & 3 & 4 & 5 & 6 & 7 \\
\hline $\begin{array}{l}\text { 6. Quarantine assists biosecurity } \\
\text { when traveling during the } \\
\text { pandemic. }\end{array}$ & 1 & 2 & 3 & 4 & 5 & 6 & 7 \\
\hline
\end{tabular}




\begin{tabular}{|c|c|c|c|c|c|c|c|}
\hline $\begin{array}{l}\text { CQ1. Values on COVID-19 } \\
\text { Biosecurity for Travel }\end{array}$ & $\begin{array}{l}\text { Strongly } \\
\text { Disagree }\end{array}$ & Disagree & $\begin{array}{l}\text { Somewhat } \\
\text { Disagree }\end{array}$ & $\begin{array}{c}\text { Neither } \\
\text { Agree nor } \\
\text { Disagree }\end{array}$ & $\begin{array}{l}\text { Somewhat } \\
\text { Agree }\end{array}$ & Agree & $\begin{array}{l}\text { Strongly } \\
\text { Agree }\end{array}$ \\
\hline $\begin{array}{l}\text { 1-8 1. Participating in travel-related } \\
\text { biosecurity is a positive behavior } \\
\text { during the pandemic. }\end{array}$ & 1 & 2 & 3 & 4 & 5 & 6 & 7 \\
\hline $\begin{array}{l}\text { 2. Participating in travel-related } \\
\text { biosecurity is a beneficial behavior } \\
\text { during the pandemic. }\end{array}$ & 1 & 2 & 3 & 4 & 5 & 6 & 7 \\
\hline $\begin{array}{l}\text { 3. Participating in travel-related } \\
\text { biosecurity is an essential behavior } \\
\text { during the pandemic. }\end{array}$ & 1 & 2 & 3 & 4 & 5 & 6 & 7 \\
\hline
\end{tabular}

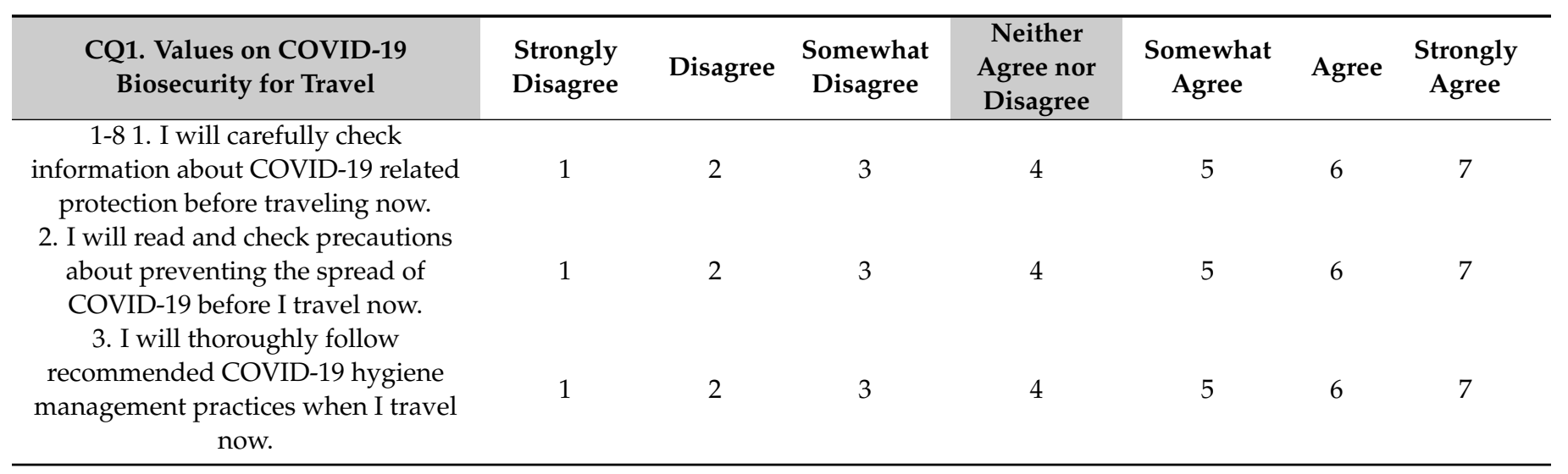

\begin{tabular}{|c|c|c|c|c|c|c|c|}
\hline $\begin{array}{l}\text { CQ1. Values on COVID-19 } \\
\text { Biosecurity for Travel }\end{array}$ & $\begin{array}{l}\text { Strongly } \\
\text { Disagree }\end{array}$ & Disagree & $\begin{array}{l}\text { Somewhat } \\
\text { Disagree }\end{array}$ & $\begin{array}{l}\text { Neither } \\
\text { Agree nor } \\
\text { Disagree }\end{array}$ & $\begin{array}{c}\text { Somewhat } \\
\text { Agree }\end{array}$ & Agree & $\begin{array}{c}\text { Strongly } \\
\text { Agree }\end{array}$ \\
\hline $\begin{array}{l}\text { 1-8 1. When traveling during the } \\
\text { pandemic, I keep away from those who } \\
\text { have the symptoms of COVID- } 19 \text {. }\end{array}$ & 1 & 2 & 3 & 4 & 5 & 6 & 7 \\
\hline $\begin{array}{l}\text { 2. While traveling during the } \\
\text { pandemic, I keep away from meeting } \\
\text { people I don't know. }\end{array}$ & 1 & 2 & 3 & 4 & 5 & 6 & 7 \\
\hline $\begin{array}{l}\text { 3. While traveling during the } \\
\text { pandemic, I keep away from meeting } \\
\text { people even if I know them. }\end{array}$ & 1 & 2 & 3 & 4 & 5 & 6 & 7 \\
\hline $\begin{array}{l}\text { 4. I only meet close friends and family } \\
\text { when travelling during the pandemic } \\
5 \text {. When traveling during the }\end{array}$ & 1 & 2 & 3 & 4 & 5 & 6 & 7 \\
\hline $\begin{array}{l}\text { pandemic, I carefully keep an eye on } \\
\text { my health condition. }\end{array}$ & 1 & 2 & 3 & 4 & 5 & 6 & 7 \\
\hline $\begin{array}{l}\text { 6. I frequently wash my hands when } \\
\text { traveling during the pandemic. }\end{array}$ & 1 & 2 & 3 & 4 & 5 & 6 & 7 \\
\hline $\begin{array}{l}\text { 7. I refrain from touching my eyes, } \\
\text { nose, and mouth when traveling } \\
\text { during the pandemic. }\end{array}$ & 1 & 2 & 3 & 4 & 5 & 6 & 7 \\
\hline 8. When traveling during the pandemic & & & & & & & \\
\hline $\begin{array}{l}\text { I cover my mouth and nose with a } \\
\text { tissue when I sneeze. }\end{array}$ & 1 & 2 & 3 & 4 & 5 & 6 & 7 \\
\hline $\begin{array}{l}\text { 9. I wear a face mask when traveling } \\
\text { during the pandemic. }\end{array}$ & 1 & 2 & 3 & 4 & 5 & 6 & 7 \\
\hline $\begin{array}{l}\text { 10. I try and avoid public areas when } \\
\text { travelling during the } \\
\text { pandemic. }\end{array}$ & 1 & 2 & 3 & 4 & 5 & 6 & 7 \\
\hline
\end{tabular}




\section{Demographic characteristics (DQ) \\ DQ1. What is your gender? \\ (1) Male (2) Female (3) Other \\ DQ2. What is your age? \\ (1) Under 20 years old \\ (2) Between 20 and 29 years old \\ (3) Between 30 and 39 years old \\ (4) Between 40 and 49 years old \\ (5) Between 50 and 59 years old \\ (6) 60 years old and over}

DQ3. What is the highest level of education you have completed?

(1) High school diploma or lower

(2) 2-year college attending or degree

(3) 4-year university attending or degree

(4) Graduate school attending or degree

DQ4. What is your marital status?

(1) Single (2) Married (3) Other (specify)

DQ5. What is your monthly household income?

(1) Less than US $\$ 2000$ (2) US $\$ 2000-3999$ (3) US $\$ 4000-5999$ (4) US $\$ 6000-7999$ (5) US $\$ 8000$ or more

DQ6. What is your occupation?

(1) Professional (e.g., attorney, engineer, architect) (2) Entrepreneur/Self-employed (3) Service employee (4) Office/Administrative/Clerical (5) Civil Servant (Government) (6) Home maker (7) Student (8) Retiree (9) Unemployment (10) Other (specify)

DQ7. In what state do you normally reside?

We thank you for your time spent taking this survey.

Your response time has been recorded!

\section{References}

1. Biscayart, C.; Angeleri, P.; Lloveras, S.; Chaves, T.D.S.S.; Schlagenhauf, P.; Rodríguez-Morales, A.J. The next Big Threat to Global Health? 2019 Novel Coronavirus (2019-NCoV): What Advice Can We Give to Travellers?-Interim Recommendations January 2020, from the Latin-American Society for Travel Medicine (SLAMVI). Travel Med. Infect. Dis. 2020, 33, 17-20. [CrossRef]

2. Bielecki, M.; Patel, D.; Hinkelbein, J.; Komorowski, M.; Kester, J.; Ebrahim, S.; Rodriguez-morales, A.J.; Memish, Z.A.; Schlagenhauf, P. Air Travel and COVID-19 Prevention in the Pandemic and Peri-Pandemic Period: A Narrative Review. Travel Med. Infect. Dis. 2021, 39, 101915. [CrossRef]

3. Chiodini, J. COVID-19 and the Impact on Travel Health Advice. Travel Med. Infect. Dis. 2020, 36, 101824. [CrossRef]

4. Hall, C.M. Biosecurity and Wine Tourism. Tour. Manag. 2005, 26, 931-938. [CrossRef]

5. Hall, C.M. Biological Invasion, Biosecurity, Tourism, and Globalisation. In Handbook of Globalisation and Tourism; Edward Elgar Publishing: Cheltenham, UK, 2020. [CrossRef]

6. Halton, K.; Sama, M.; Barnett, A.; Leonardo, L.; Graves, N. A Systematic Review of Community-Based Interventions for Emerging Zoonotic Infectious Diseases in Southeast Asia. JBI Database Syst. Rev. Implement Rep. 2013, 11, 1-235. [CrossRef]

7. Schiavo, R.; May Leung, M.; Brown, M. Communicating Risk and Promoting Disease Mitigation Measures in Epidemics and Emerging Disease Settings. Pathog. Glob. Health 2014, 108, 76-94. [CrossRef]

8. World Health Organization (WHO). Ebola Strategy: Ebola and Marburg Virus Disease Epidemics: Preparedness, Alert, Control, and Evaluation. Available online: https://apps.who.int/iris/handle/10665/130160 (accessed on 20 January 2020).

9. Findlater, A.; Bogoch, I.I. Human Mobility and the Global Spread of Infectious Diseases: A Focus on Air Travel. Trends Parasitol. 2018, 34, 772-783. [CrossRef] [PubMed]

10. Hall, C.M. Tourism and Social Marketing; Routledge: London, UK, 2014. [CrossRef]

11. Hall, C.M.; Scott, D.; Gössling, S. Pandemics, Transformations and Tourism: Be Careful What You Wish For. Tour. Geogr. 2020, 22, 577-598. [CrossRef]

12. Williams, N.L.; Nguyen, T.H.H.; Del Chiappa, G.; Fedeli, G.; Wassler, P. COVID-19 Vaccine Confidence and Tourism at the Early Stage of a Voluntary Mass Vaccination Campaign: A PMT Segmentation Analysis. Curr. Issues Tour. 2021, 1-15. [CrossRef]

13. Baird, T.; Hall, C.M.; Castka, P. New Zealand Winegrowers Attitudes and Behaviours towards Wine Tourism and Sustainable Winegrowing. Sustainability 2018, 10, 797. [CrossRef] 
14. Lee, C.K.; Song, H.J.; Bendle, L.J.; Kim, M.J.; Han, H. The Impact of Non-Pharmaceutical Interventions for 2009 H1N1 Influenza on Travel Intentions: A Model of Goal-Directed Behavior. Tour. Manag. 2012, 33, 89-99. [CrossRef] [PubMed]

15. Decraene, V.; Kühlmann Berenzon, S.; Andersson Franko, M.; Veličko, I. Differences in Travel-Related Incidence of Chlamydia by Age Groups, Gender and Destination: Sweden 2000-2013. Travel Med. Infect. Dis. 2018, 25, 42-49. [CrossRef]

16. Racicot, M.; Venne, D.; Durivage, A.; Vaillancourt, J.P. Evaluation of Strategies to Enhance Biosecurity Compliance on Poultry Farms in Québec: Effect of Audits and Cameras. Prev. Vet. Med. 2012, 103, 208-218. [CrossRef]

17. Pérez-Molina, J.A.; López-Polín, A.; Treviño, B.; Molina, I.; Goikoetxea, J.; Díaz-Menéndez, M.; Torrús, D.; Calabuig, E.; Benito, A.; López-Vélez, R. 6-Year Review of +Redivi: A Prospective Registry of Imported Infectious Diseases in Spain. J. Travel Med. 2017, 24, 1-7. [CrossRef]

18. Chen, X.; Gao, D. Effects of Travel Frequency on the Persistence of Mosquito-Borne Diseases. Discret. Contin. Dyn. Syst.-B 2020, 25, 4677-4701. [CrossRef]

19. Gao, D. Travel Frequency and Infectious Diseases. Soc. Ind. Appl. Math. 2019, 79, 1581-1606. [CrossRef]

20. Chua, B.-L.; Al-Ansi, A.; Lee, M.J.; Han, H. Impact of Health Risk Perception on Avoidance of International Travel in the Wake of a Pandemic. Curr. Issues Tour. 2020, 24, 985-1002. [CrossRef]

21. Neuburger, L.; Egger, R. Travel Risk Perception and Travel Behaviour during the COVID-19 Pandemic 2020: A Case Study of the DACH Region. Curr. Issues Tour. 2020, 24, 1003-1016. [CrossRef]

22. Bronfman, N.; Repetto, P.; Cordón, P.; Castañeda, J.; Cisternas, P. Gender Differences on Psychosocial Factors Affecting COVID-19 Preventive Behaviors. Sustainability 2021, 13, 6148. [CrossRef]

23. Marco-Franco, J.E.; Guadalajara-Olmeda, N.; González-de Julián, S.; Vivas-Consuelo, D. COVID-19 Healthcare Planning: Predicting Mortality and the Role of the Herd Immunity Barrier in the General Population. Sustainability 2020, 12, 5228. [CrossRef]

24. Hayir-Kanat, M.; Breuste, J. Outdoor Recreation Participation in Istanbul, Turkey: An Investigation of Frequency, Length, Travel Time and Activities. Sustainability 2020, 12, 741. [CrossRef]

25. Plevka, V.; Astegiano, P.; Himpe, W.; Tampère, C.; Vandebroek, M. How Personal Accessibility and Frequency of Travel Affect Ownership Decisions on Mobility Resources. Sustainability 2018, 10, 912. [CrossRef]

26. Kim, M.J.; Hall, C.M.; Bonn, M. Does International Travel Frequency Affect COVID-19 Biosecurity Behavior in the United States? Int. J. Environ. Res. Public Health 2021, 18, 4111. [CrossRef] [PubMed]

27. Hall, C.M. Biosecurity, Tourism and Mobility: Institutional Arrangements for Managing Tourism-Related Biological Invasions. J. Policy Res. Tour. Leis. Events 2011, 3, 256-280. [CrossRef]

28. Seyfi, S.; Hall, C.M.; Shabani, B. COVID-19 and International Travel Restrictions: The Geopolitics of Health and Tourism. Tour. Geogr. 2020. [CrossRef]

29. Ahmad, T.; Haroon, H.; Dhama, K.; Sharun, K.; Khan, F.M.; Ahmed, I.; Tiwari, R.; Musa, T.H.; Khan, M.; Bonilla-Aldana, D.K.; et al. Biosafety and Biosecurity Approaches to Restrain/Contain and Counter SARS-CoV-2/COVID-19 Pandemic: A Rapid-Review. Turkish J. Biol. 2020, 44, 132-145. [CrossRef] [PubMed]

30. Ivanov, S.H.; Webster, C.; Stoilova, E.; Slobodskoy, D. Biosecurity, Crisis Management, Automation Technologies and Economic Performance of Travel, Tourism and Hospitality Companies-A Conceptual Framework. Tour. Econ. 2020. [CrossRef]

31. Kim, M.J.; Bonn, M.; Hall, C.M. Traveler Biosecurity Behavior during the COVID-19 Pandemic: Effects of Intervention, Resilience, and Sustainable Development Goals. J. Travel Res. 2021, in press. [CrossRef]

32. Kim, M.J.; Bonn, M.; Hall, C.M. What Influences COVID-19 Biosecurity Behaviour for Tourism? Curr. Issues Tour. 2021, 1-7. [CrossRef]

33. Kim, M.J.; Hall, C.M.; Bonn, M. Can the Value-Attitude-Behavior Model and Personality Predict International Tourists' Biosecurity Practice during the Pandemic? J. Hosp. Tour. Manag. 2021, 48, 99-109. [CrossRef]

34. Salmon, D.A.; Dudley, M.Z.; Brewer, J.; Kan, L.; Gerber, J.E.; Budigan, H.; Proveaux, T.M.; Bernier, R.; Rimal, R.; Schwartz, B. COVID-19 Vaccination Attitudes, Values and Intentions among United States Adults Prior to Emergency Use Authorization. Vaccine 2021, 39, 2698-2711. [CrossRef]

35. Kim, M.J.; Hall, C.M.; Kim, D.K. Predicting Environmentally Friendly Eating out Behavior by Value-Attitude-Behavior Theory: Does Being Vegetarian Reduce Food Waste? J. Sustain. Tour. 2020, 28, 797-815. [CrossRef]

36. Kantor, B.N.; Kantor, J. Non-Pharmaceutical Interventions for Pandemic COVID-19: A Cross-Sectional Investigation of US General Public Beliefs, Attitudes, and Actions. Front. Med. 2020, 7, 1-6. [CrossRef]

37. Xu, H.; Gan, Y.; Zheng, D.; Wu, B.; Zhu, X.; Xu, C.; Liu, C.; Tao, Z.; Hu, Y.; Chen, M.; et al. Relationship between COVID-19 Infection and Risk Perception, Knowledge, Attitude, and Four Nonpharmaceutical Interventions during the Late Period of the COVID-19 Epidemic in China: Online Cross-Sectional Survey of 8158 Adults. J. Med. Internet Res. 2020, 22, e21372. [CrossRef] [PubMed]

38. Yapi, R.B.; Houngbedji, C.A.; N'guessan, D.K.G.; Dindé, A.O.; Sanhoun, A.R.; Amin, A.; Gboko, K.D.T.; Heitz-Tokpa, K.; Fokou, G.; Bonfoh, B. Knowledge, Attitudes, and Practices (Kap) Regarding the Covid-19 Outbreak in Côte d'ivoire: Understanding the Non-Compliance of Populations with Non-Pharmaceutical Interventions. Int. J. Environ. Res. Public Health 2021, $18,4757$. [CrossRef]

39. Galasso, V.; Pons, V.; Profeta, P.; Becher, M.; Brouard, S.; Foucault, M. Gender Differences in COVID-19 Attitudes and Behavior: Panel Evidence from Eight Countries. Proc. Natl. Acad. Sci. USA 2020, 117, 27285-27291. [CrossRef] [PubMed] 
40. Xu, W.; Youn, H.J.; Lee, C.K. Role of Non-Pharmaceutical Interventions for COVID-19 in Cruise Tourists' Decision-Making Process: An Extended Model of Goal-Directed Behavior. Sustainability 2021, 13, 5552. [CrossRef]

41. Peluso, A.M.; Pichierri, M. Vacation Preferences in the COVID-19 Era: An Investigation of Age-Related Effects. Curr. Issues Tour. 2021, 24, 2710-2715. [CrossRef]

42. Churchill, G.A., Jr. A Paradigm for Developing Better Measures of Marketing Constructs. J. Mark Res. 1979, 16, 64-73. [CrossRef]

43. Ryu, S.; Gao, H.; Wong, J.Y.; Shiu, E.Y.C.; Xiao, J.; Fong, M.W.; Cowling, B.J. Nonpharmaceutical Measures for Pandemic Influenza in Nonhealthcare Settings-International Travel-Related Measures. Emerg. Infect. Dis. 2020, 26, 2298-2299. [CrossRef] [PubMed]

44. Wright, K.B. Researching Internet-Based Populations: Advantages and Disadvantages of Online Survey Research, Online Questionnaire Authoring Software Packages, and Web Survey Services. J. Comput. Commun. 2005, 10, JCMC1034. [CrossRef]

45. Qualtrics. Research Services: Online Sample (Panels and Samples). Available online: https://www.https//www.qualtrics.com/ research-services/online-sample/ (accessed on 28 August 2020).

46. National Travel \& Tourism Office. Outbound Travel from the U.S. Available online: https://travel.trade.gov/outreachpages / outbound.general_information.outbound_overview.asp (accessed on 25 August 2020).

47. Ringle, C.M.; Wende, S.; Becker, J.M. SmartPLS 3.3.3. Available online: http:/ / www.smartpls.com (accessed on 14 September 2020).

48. Hair, J.F.J.; Sarstedt, M.; Ringle, C.M.; Gudergan, S.P. Advanced Issues in Partial Least Squares Structural Equation Modeling; Sage Publications: New York, NY, USA, 2017.

49. Hair, J.F.; Sarstedt, M.; Ringle, C.M.; Mena, J.A. An Assessment of the Use of Partial Least Squares Structural Equation Modeling in Marketing Research. J. Acad. Mark Sci. 2012, 40, 414-433. [CrossRef]

50. Chin, W.W.; Marcolin, B.L.; Newsted, P.R. A Partial Least Squares Latent Variable Modeling Approach for Measuring Interaction Effects: Results from a Monte Carlo Simulation Study and Electronic-Mail Emotion/Adoption Study. Inf. Syst. Res. 2003, 14, 189-217. [CrossRef]

51. Keil, M.; Tan, B.C.Y.; Wei, K.; Saarinen, T.; Tuunainen, V.; Wassenaar, A. A Cross-Cultural Study on Escalation of Commitment Behavior in Software Projects. MIS Q. 2000, 24, 299-325. [CrossRef]

52. Van Wee, B.; Witlox, F. COVID-19 and Its Long-Term Effects on Activity Participation and Travel Behaviour: A Multiperspective View. J. Transp. Geogr. 2021, 95, 103144. [CrossRef] [PubMed]

53. Yu, M.; Li, Z.; Yu, Z.; He, J.; Zhou, J. Communication Related Health Crisis on Social Media: A Case of COVID-19 Outbreak. Curr. Issues Tour. 2021, 24, 2699-2705. [CrossRef]

54. Pavli, A.; Maltezou, H.C. COVID-19 Vaccine Passport for Safe Resumption of Travel. J. Travel Med. 2021, 28, 1-3. [CrossRef] [PubMed] 